\title{
Studi Sumber Gempa Ambon 26 September 2019 Mw 6,5
}

\author{
Dimas Sianipar $^{1 *}$, Yehezkiel Halauwet ${ }^{2}$, Daryono $^{3}$, Dwikorita Karnawati ${ }^{3}$ \\ ${ }^{1}$ Sekolah Tinggi Meteorologi, Klimatologi, dan Geofisika (STMKG), Tangerang Selatan \\ ${ }^{2}$ Badan Meteorologi, Klimatologi, dan Geofisika (BMKG), Stasiun Geofisika Karang \\ Panjang, Ambon \\ ${ }^{3}$ Badan Meteorologi, Klimatologi, dan Geofisika (BMKG), Jakarta Pusat \\ *Email: dsj.sianipar@stmkg.ac.id
}

\begin{abstract}
Abstrak
Pada tanggal 26 September 2019 pukul 06:46 WIB gempabumi bermagnitudo Mw 6,5 terjadi di wilayah Ambon dan mengakibatkan adanya korban jiwa dan kerusakan infrastruktur. Penjelasan yang rinci tentang mekanisme sumber gempa ini masih belum ada. Dalam penelitian ini, kami menggunakan metode inversi gelombang seismik untuk menjelaskan proses rupture dan distribusi slip koseismik menggunakan data gelombang badan dan gelombang permukaan teleseismik. Hasil menunjukkan bahwa bidang sesar dengan arah ke utara (strike $=347^{\circ}$ dan dip $=70^{\circ}$ ) lebih cocok untuk dimodelkan dengan rekaman displacement observasi dan sesuai dengan distribusi gempa susulan. Rupture terinisiasi dari kedalaman 9 $\mathrm{km}$ dan bergerak secara bilateral tetapi dominan ke selatan. Slip maksimum bernilai $90 \mathrm{~cm}$ tercapai kurang dari 3 detik pada kedalaman $6,2 \mathrm{~km}$. Bidang rupture berada pada kedalaman $\sim 2$ - $24 \mathrm{~km}$ dengan luas sekitar $567 \mathrm{~km}^{2}$. Rata-rata dari amplitudo slip di bidang rupture adalah 29,4 cm. Asperity berada di bagian up-dip dan di selatan dari initial break, dengan luas sekitar $144 \mathrm{~km}^{2}$ (25\% dari total luas rupture). Momen seismik total yang dihasilkan dari gempa ini yaitu $6,60 \times 10^{18} \mathrm{Nm}$ atau setara dengan magnitudo momen $M w=6,47$. Gempa Ambon 2019 ini memiliki nilai stress drop yang rendah. Pemodelan stress menggunakan masukan slip hasil inversi menunjukkan bahwa gempa susulan dipromosikan oleh perubahan Coulomb stress yang positif pada kedalaman yang lebih dangkal $(0-10 \mathrm{~km})$. Gempa susulan di bagian barat-daya sesar (di bagian Pulau Ambon) lebih cocok dipromosikan oleh perubahan Coulomb stress positif pada kedalaman yang lebih dalam (10-30 km). Dalam penelitian ini juga didiskusikan kaitan antara parameter koseismik dan parameter seismisitas (gempa pendahuluan dan susulan). Gempa Ambon 2019 terjadi di sesar strike-slip dengan gerakan right-lateral yang berada di antara pulau Ambon dan Haruku memanjang ke utara di sebelah barat daya Kairatu, Pulau Seram. Sesar ini belum teridentifikasi sebelumnya dan keberadaannya berpengaruh terhadap bahaya kegempaan di Ambon dan sekitarnya.
\end{abstract}

Kata kunci: gempa Ambon 2019, finite fault, rupture, slip, stress drop, Coulomb stress, foreshocks, aftershocks, $b$-value, p-value

\section{Pendahuluan}

Gempa Ambon 2019 terjadi pada tanggal 26 September 2019 pukul 06:46 WIB dengan magnitudo 6,6 $\mathrm{Mw}(\mathrm{mB})$ menurut Badan Meteorologi, Klimatologi, dan Geofisika (BMKG). Pusat gempabumi berada di koordinat $-3,42^{\circ} \mathrm{LU}, 128,45^{\circ} \mathrm{BT}$ pada kedalaman $10 \mathrm{~km}$ menurut hasil pemutakhiran BMKG. Gempa ini dirasakan oleh masyarakat dengan intensitas 
maksimum mencapai VI MMI (Modified Mercally Intensity) dan menyebabkan kerusakan infrastruktur dan rumah masyarakat, serta menelan korban jiwa sedikitnya 30 orang.

Penjelasan yang rinci mengenai mekanisme sumber gempa ini masih belum ada. Lokasi pusat gempa merupakan wilayah yang aktif secara tektonik. Wilayah Pulau Seram dan sekitarnya berada dekat dengan palung Seram yang dapat membangkitkan gempa besar dengan tipe penyesaran naik (thrust). Menurut data BMKG, gempa Ambon 2019 merupakan gempa dengan tipe penyesaran strike slip pada lapisan kerak (crustal earthquake). Berdasarkan produk moment tensor gempa BMKG, gempa ini bisa terjadi akibat dari penyesaran mendatar dengan arah utara-selatan dengan dip yang hampir vertikal dengan pergerakan right lateral (bidang nodal 1: strike $=166^{\circ}$, dip $=81^{\circ}$, rake $=180^{\circ}$ ), atau akibat dari pergerakan left-lateral dengan arah timur-barat (bidang nodal 2: strike $=256^{\circ}$, dip $=90^{\circ}$, rake $=10^{\circ}$ ). Produk moment tensor BMKG ini dihasilkan lewat inversi seismik menggunakan data regional BMKG melalui perangkat lunak Seiscomp3. Produk BMKG ini juga sesuai dengan hasil mekanisme sumber dari berbagai lembaga pengamatan gempa. Pembangkit gempa ini bisa berupa struktur yang melintasi wilayah Kairatu bagian selatan berarah timur-barat yang secara umum sesuai dengan lineasi strike slip di bagian utara dan selatan Pulau Seram, atau bisa juga dibangkitkan oleh struktur berarah utara-selatan yang mungkin belum teridentifikasi.

Penyesaran dengan tipe strike-slip dan thrust di sekitar pulau Seram merupakan hal yang wajar secara tektonik sebagai akibat dari deformasi yang intens berkaitan dengan konvergensi antara lempeng Australia, Eurasia dan Pasifik dan beberapa microplate dengan skala dan kecepatan yang berbeda-beda. Beberapa struktur strike slip dan thrust di wilayah ini telah teridentifikasi sebelumnya dan sudah masuk dalam Peta Sumber dan Bahaya Gempa Indonesia tahun 2017. Keberadaan sesar aktif penting untuk diidentifikasi dalam penilaian bahaya seismik di masa yang akan datang.

BMKG melaporkan bahwa gempa utama didahului oleh beberapa gempa pendahuluan yang terjadi beberapa bulan sebelumnya (Gambar 1). Gempa utama juga diikuti oleh ribuan gempa susulan menurut hasil pengamatan BMKG. Distribusi gempa susulan menunjukkan pola yang berarah utara-selatan. Pada penelitian ini, kami menggunakan inversi gelombang seismik untuk menyediakan model penyesaran yang dapat menjelaskan proses rupture dan distribusi slip koseismik saat gempa utama terjadi.

\section{Metode}

Respon dari penyesaran gempa pada sebuah stasiun seismik dapat diestimasi dengan penjumlahan masing-masing kontribusi dari grid yang regular (sub-faults) seperti yang ditunjukkan pada formula (Ji dkk., 2002) (Gambar 2):

$$
u(t)=\sum_{j=1}^{n} \sum_{k=1}^{n} D_{j k}\left[\cos \lambda_{j k} Y_{j k}^{1}\left(V_{j k}, t\right)+\sin \lambda_{j k} Y_{j k}^{2}\left(V_{j k}, t\right)\right] \dot{S}_{j k}(t)
$$

yang mana $u(t)$ merupakan displacement pada sebuah stasiun seismik, $j$ adalah sub-fault ke-j sepanjang strike, $k$ adalah sub-fault ke-k sepanjang dip. $D_{j k}, \lambda_{j k}, \dot{S}_{j k}(t)$ masing-masing adalah rata-rata amplitudo slip, sudut rake dan fungsi rise-time. Vjk adalah kecepatan rata-rata rupture antara hiposenter dan sub-fault $j k . Y_{j k}^{1}\left(V_{j k}, t\right)$ dan $Y_{j k}^{2}\left(V_{j k}, t\right)$ adalah fungsi Green's $s u b$ fault untuk unit slip di arah strike dan arah down-dip. 
Pada studi ini, digunakan metode inversi waveform dengan transformasi wavelet (Ji dkk., 2002; Hao dkk., 2017). Inversi ini merupakan inversi non-linear yang menerapkan metode simulated annealing yang secara simultan mencari parameter sumber gempa, yaitu nilai amplitudo slip, arah slip, sudut rake, waktu inisiasi rupture, kecepatan rupture dan fungsi laju slip untuk setiap sub-fault. Pada inversi ini, fungsi laju slip diestimasi dengan fungsi kosinus yang asimetrik dengan waktu awal dan akhir yang bervariasi (Ji dkk., 2002).
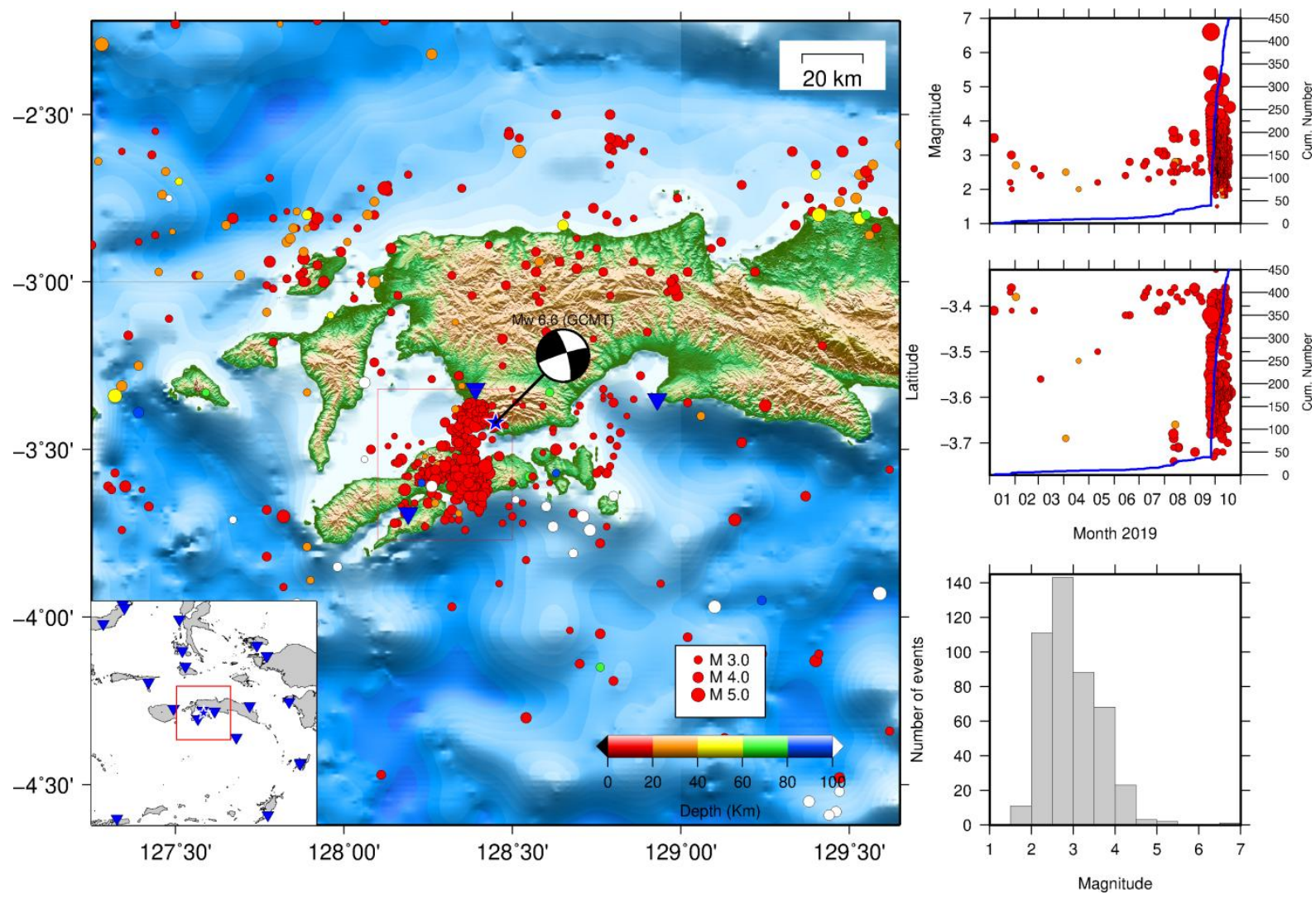

Gambar 1. Seismisitas di sekitar bagian barat Pulau Seram, Maluku, Indonesia dari 1 Januari - 18 Oktober 2019 berdasarkan katalog Pusat Gempabumi dan Tsunami BMKG (www.inatews.bmkg.go.id). Beachball menunjukkan mekanisme sumber gempa Ambon 26 September 2019 (GCMT). Kotak merah menunjukkan wilayah yang seismisitasnya dipetakan dalam tiga grafik di panel bagian kanan.

Secara ringkas, mekanisme sumber gempa yang dikeluarkan oleh beberapa lembaga (misalnya, BMKG, USGS, Geoscope IPGP, Global CMT, Geofon GFZ dan IRIS) menunjukkan kesesuaian satu dengan yang lainnya yaitu gempa disebabkan oleh penyesaran bertipe strike-slip pada kedalaman dangkal di lapisan kerak. Pada studi ini, dilakukan inversi waveform dengan menggunakan data gelombang badan (body-waves) dan gelombang permukaan (surface-waves) teleseismik. Data teleseismik digunakan untuk menghindari gangguan dari heterogenitas struktur mantel bagian atas.

Bidang sesar dimodelkan sebagai suatu persegi panjang tunggal dengan panjang $45 \mathrm{~km}$ dan lebar $30 \mathrm{~km}$ yang dibagi menjadi 150 bagian (sub-fault) dengan ukuran $3 \times 3 \mathrm{~km}$ masingmasing. Dalam hal ini, bidang sesar mempunyai 15 sub-fault sepanjang strike, dan 10 subfault sepanjang dip (Gambar 2). Posisi hiposenter gempa utama (initial break) yang digunakan merupakan hiposenter yang sudah direlokasi menggunakan data BMKG (Yehezkiel Halauwet, 2019), yaitu pada koordinat $128,32^{\circ} \mathrm{BT},-3,40^{\circ} \mathrm{LU}$ pada kedalaman 9 $\mathrm{km}$. Initial break ini ditempatkan pada sub-fault ke-11 sepanjang strike, dan sub-fault ke-3 
sepanjang dip. Bidang nodal pertama memiliki parameter strike $=347^{\circ}$ dan dip $=70^{\circ}$. Bidang nodal kedua memiliki parameter strike $=253^{\circ}$ dan $\operatorname{dip}=84^{\circ}$ (Tabel 1).

Menurut scaling law yang biasa digunakan dalam ilmu seismologi (Wells and Coppersmith, 1994), gempa dengan magnitudo momen 6,5 - 6,6 bertipe strike-slip biasanya dihasilkan oleh rupture dengan ukuran panjang 29 - $34 \mathrm{~km}$ dan lebar sekitar $12 \mathrm{~km}$. Digunakannya model dengan ukuran sedikit lebih besar $(45 \times 30 \mathrm{~km})$ dalam studi ini adalah untuk mempertimbangkan bahwa rupture dapat menjalar secara bilateral ke dua arah dengan berpusat di initial break, juga dapat memperluas ke arah down-dip hingga batas kedalaman seismogenik di lapisan kerak bagian bawah (lower crust) dekat diskontinuitas Moho.

Untuk membuat pekerjaan inversi lebih ringan, diberikan beberapa batasan inisial. Kecepatan rupture $(\mathrm{Vr})$ di awal merupakan kecepatan konstan sebesar 3,3 $\mathrm{km} /$ detik tetapi selama proses inversi, dicari kecepatan rupture terbaik pada rentang $1,65-4,95 \mathrm{~km} / \mathrm{detik}$. Sudut rake yang paling optimal juga dicari pada rentang $90-270^{\circ}$ (bidang nodal 1, right-lateral) atau $270-90^{\circ}$ (bidang nodal 2, left-lateral). Konvensi sudut rake di sini dihitung dari $0^{\circ}$ ke $360^{\circ}$. Total momen seismik juga dibatasi pada nilai momen yang dihasilkan oleh model sumber titik dari Global CMT yaitu sebesar $6,60 \times 10^{18} \mathrm{Nm}$.

Inversi dilakukan dengan mencari model yang paling cocok (waveform fitting) dengan data observasi. Data yang digunakan adalah data gelombang badan dan gelombang permukaan teleseismik yang diunduh melalui IRIS (Incorporated Research Institutions for Seismology) yaitu untuk stasiun seismik pada jarak $30-90^{\circ}$ dari sumber gempa. Pemilihan data seismik dilakukan dengan mempertimbangkan kualitas sinyal (signal-to-noise ratio) dan distribusi azimuth dari stasiun seismik yang akan digunakan. Panjang data gelombang badan yang digunakan yaitu 51,2 detik untuk masing-masing sinyal dengan sampling tiap 0,2 detik.

Setelah dilakukan koreksi dengan respon instrumen, digunakan data displacement frekuensi rendah yang disaring dalam rentang frekuensi kurang dari $0,4 \mathrm{~Hz}$ untuk gelombang badan. Dalam studi ini digunakan sebanyak 38 gelombang badan (19 gelombang P, 19 gelombang $\mathrm{SH})$, dan 35 gelombang permukaan (19 gelombang Rayleigh dan 16 gelombang Love). Untuk gelombang permukaan, sinyal disaring lebih rendah dari 0,007 Hz. Fungsi Green's dihitung menggunakan model kecepatan dari model CRUST2.0 dan PREM (Tabel 2).

Tabel 1. Parameter inisial gempa utama untuk inversi finite fault

\begin{tabular}{cccccccc}
\hline Tanggal & $\begin{array}{c}\text { Origin } \\
\text { time } \\
(\mathbf{U T C})\end{array}$ & $\begin{array}{c}\text { Episenter } \\
\left({ }^{\circ} \mathbf{B T},\right. \\
\left.{ }^{\circ} \mathbf{L U}\right)\end{array}$ & $\begin{array}{c}\text { Strike } \\
\boldsymbol{\theta}\left({ }^{\circ}\right)\end{array}$ & $\begin{array}{c}\text { Dip } \\
\boldsymbol{\delta}\left({ }^{\circ}\right)\end{array}$ & $\begin{array}{c}\text { Rake } \\
\lambda\left({ }^{\circ}\right)\end{array}$ & $\begin{array}{c}\text { Mo } \\
\left(\mathbf{1 0}^{\mathbf{1 8}} \mathbf{N m}\right)\end{array}$ & $\begin{array}{c}\text { Rentang } \\
\mathbf{V r} \\
(\mathbf{k m} / \mathbf{s})\end{array}$ \\
\hline $2019-09-25$ & $23: 46: 44$ & $\begin{array}{c}128,32, \\
-3,40\end{array}$ & 347 & 70 & $90-270$ & \multirow{2}{*}{6,60} & $1,65-4,95$ \\
\hline
\end{tabular}

Tabel 2. Model kecepatan yang digunakan dalam studi ini

\begin{tabular}{cccccc}
\hline $\begin{array}{c}\mathbf{V p} \\
(\mathbf{k m} / \mathbf{s})\end{array}$ & $\begin{array}{c}\mathbf{V s} \\
(\mathbf{k m} / \mathbf{s})\end{array}$ & $\boldsymbol{\rho}$ (Densitas) & $\begin{array}{c}\text { Ketebalan } \\
(\mathbf{k m})\end{array}$ & $\mathbf{Q p}$ & $\mathbf{Q s}$ \\
\hline 1,50 & 0,01 & 1,02 & 1,3 & 1000 & 500 \\
2,10 & 1,00 & 2,10 & 1,0 & 1000 & 500 \\
6,00 & 3,40 & 2,70 & 7,0 & 1000 & 500 \\
6,60 & 3,70 & 2,90 & 7,0 & 1000 & 500 \\
7,20 & 4,00 & 3,05 & 7,0 & 1000 & 500
\end{tabular}




\begin{tabular}{cccccc}
8,08 & 4,47 & 3,38 & 196,0 & 1200 & 500 \\
8,59 & 4,66 & 3,45 & 36,0 & 360 & 140 \\
8,73 & 4,71 & 3,49 & 108,0 & 370 & 140 \\
8,87 & 4,76 & 3,53 & 36,0 & 370 & 140 \\
9,22 & 4,98 & 3,74 & 33,3 & 370 & 140 \\
9,56 & 5,18 & 3,83 & 100,0 & 360 & 140 \\
9,90 & 5,37 & 3,91 & 33,3 & 360 & 140 \\
10,07 & 5,47 & 3,95 & 33,3 & 360 & 140 \\
10,21 & 5,54 & 3,98 & 70,0 & 360 & 140 \\
10,79 & 5,98 & 4,39 & 25,3 & 760 & 310 \\
10,87 & 6,06 & 4,40 & 0,0 & 750 & 310 \\
\hline
\end{tabular}

\section{Hasil dan Pembahasan}

Hasil menunjukkan bahwa bidang nodal dengan orientasi ke utara $\left(\right.$ strike $=347^{\circ}$ dan $\left.\operatorname{dip}=70^{\circ}\right)$ lebih cocok untuk dimodelkan dengan rekaman displacement observasi teleseismik. Error minimum dengan model ini yaitu 0,3182973 yang tergolong cukup baik dalam studi sumber gempa. Kesesuaian antara sinyal sintetik dari model dengan sinyal observasi (waveform fitting) lebih baik bagi model ini (Gambar S2-S3). Hal ini juga didukung dengan kluster gempa susulan yang terdistribusi berarah utara-selatan yang dapat dilihat pada Gambar 1 . Sementara untuk bidang nodal kedua, error minimum yang dihasilkan sebesar 0,3290477.

Tabel 3. Hasil parameter sumber gempa Ambon 2019 yang rinci

\begin{tabular}{ll}
\hline \multicolumn{1}{c}{ Parameter Gempa Ambon 2019 } & \multicolumn{1}{c}{ Hasil } \\
\hline Kedalaman inisiasi (hiposenter) $(\mathrm{km})$ & 9,0 \\
Kedalaman slip maksimum $(\mathrm{km})$ & 6,2 \\
Ekstensi kedalaman rupture $(\mathrm{km})$ & $\sim 2-24$ \\
Luas rupture $(\mathrm{RA})\left(\mathrm{km}^{2}\right)$ & $63 \times 9=567$ \\
Kedalaman asperity $(\mathrm{S}>1,5 \times \dot{D})(\mathrm{km})$ & $\sim 2-10$ \\
Luas asperity $(\mathrm{SA})\left(\mathrm{km}^{2}\right)$ & $16 \times 9=144$ \\
$\mathrm{SA} / \mathrm{RA}$ & $25 \%$ \\
Momen seismik $\left(10^{18} \mathrm{Nm}\right)(\mathrm{Mw})$ & $6,60(6,47)$ \\
Amplitudo slip maksimum $(\mathrm{cm})$ & 90,1 \\
Rata-rata amplitudo slip $\dot{D}(\mathrm{~cm})$ & 29,4 \\
Durasi rupture $(\mathrm{s})$ & 21 \\
Rata-rata sudut rake $\left({ }^{\circ}\right)$ & 210 \\
$\mathrm{~L}_{\text {eff }}(\mathrm{km})$ & 34 \\
$\mathrm{~W}_{\text {eff }}(\mathrm{km})$ & 17 \\
Stress drop (bars) & $2,14-4,28$ \\
\hline
\end{tabular}

Rupture didominasi dengan pergerakan strike slip dengan sedikit komponen turun (normal) utamanya di sekitar asperity. Rupture ini terinisiasi dari kedalaman $9 \mathrm{~km}$ dan bergerak secara bilateral tetapi dominan ke selatan. Slip maksimum bernilai $90 \mathrm{~cm}$ tercapai kurang dari 3 detik pada kedalaman dangkal $6,2 \mathrm{~km}$. Untuk mempertimbangkan ketidakpastian hasil inversi, wilayah yang disebut rupture harus memiliki amplitudo slip minimal $10 \%$ dari slip maksimum. Bidang rupture ini berada pada kedalaman 2 - $24 \mathrm{~km}$ dengan luas sekitar 567 $\mathrm{km}^{2}$. Rata-rata dari amplitudo slip di bidang rupture adalah $29,4 \mathrm{~cm}$. Asperity didefenisikan sebagai wilayah dengan nilai amplitudo slip yang lebih besar dari 1,5 kali rata-rata slip. 
Rupture gempa Ambon hanya memiliki satu asperity besar (Gambar 2). Asperity ini berada di bagian up-dip dan di selatan dari initial break, dengan luas sekitar $144 \mathrm{~km}^{2}$ (25\% dari total luas rupture). Momen seismik total yang dihasilkan dari gempa ini yaitu $6,60 \times 10^{18} \mathrm{Nm}$ atau setara dengan magnitudo momen $M w=6,47$.

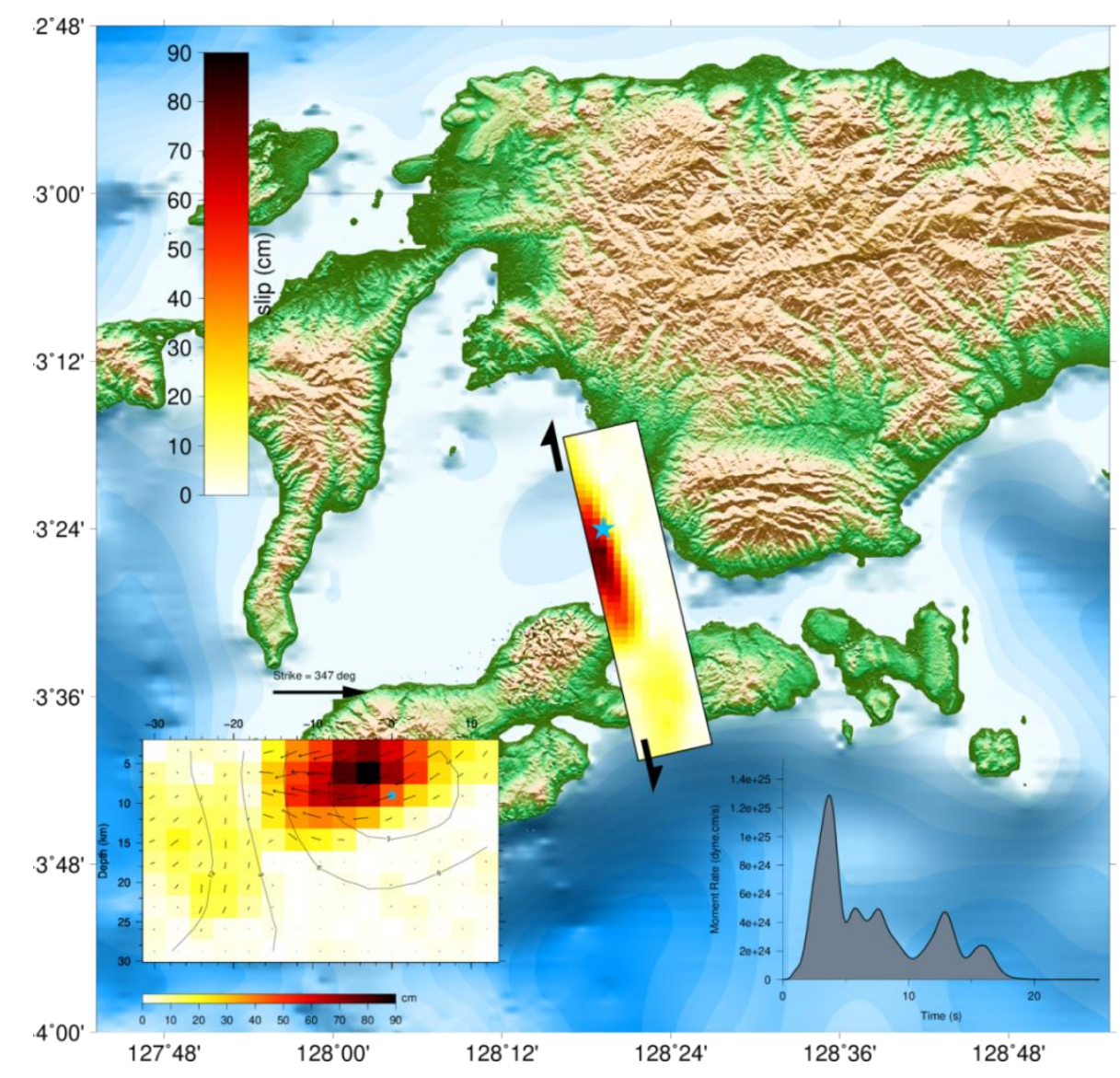

Gambar 2. Proses rupture dan distribusi slip gempa Ambon 26 September 2019. Bintang biru merupakan hiposenter (initial break) gempa utama. Warna menunjukkan amplitudo slip. Pada panel bawah kiri ditunjukkan penampang distribusi slip terhadap kedalaman. Panah merupakan arah rake pada masing-masing sub-fault. Kontur menunjukkan waktu propagasi rupture. Pada bagian kanan bawah merupakan fungsi laju momen.

Dimensi sesar yang paling efektif dapat diestimasi dengan metode autocorrelation width $\left(W^{A F C}\right)$ yang diusulkan oleh Mai dan Beroza (2000). Slip sepanjang arah strike dan dip masing-masing dijumlahkan untuk menunjukkan fungsi slip yang ditujukan untuk menghitung panjang sesar efektif $\left(\mathrm{L}_{\text {eff }}\right)$ dan lebar sesar efektif $\left(\mathrm{W}_{\text {eff }}\right)$. Kemudian, $\mathrm{L}_{\text {eff }}$ dan $\mathrm{W}_{\text {eff }}$ dihitung dengan menormalkan luas di bawah fungsi korelasi diri dengan fungsi korelasi diri zero lag (ACF) seperti yang ditunjukkan oleh rumus:

$$
W^{A C F}=\frac{\int_{-\infty}^{\infty}(f * f) \mathrm{dx}}{\left.f * f\right|_{x=0}} .
$$

Menggunakan rumus di atas, untuk gempa Ambon 2019 didapatkan ukuran efektif rupture sebesar $34 \mathrm{~km}$ x $17 \mathrm{~km}$. Kemudian stress drop dapat dihitung dengan rumus:

$$
\Delta \sigma=C \frac{M o}{A L}
$$


yang mana $C$ adalah konstanta non-dimensional yang bergantung pada geometri sesar $(\mathrm{C}=2 / \pi$ untuk strike-slip) (Kanamori dan Anderson, 1975), $M_{o}$ adalah total momen seismik, A adalah luas rupture dan L adalah panjang atau lebar sesar. Stress drop gempa Ambon dihitung sebesar sekitar 2,14 - 4,28 bars (0,2-0,4 MPa).

Menggunakan distribusi slip hasil inversi, perubahan Coulomb stress statik dari gempa utama juga dapat dihitung menggunakan rumus:

$$
\Delta C F F=\Delta \tau+\mu(\Delta \sigma n+\Delta P)
$$

yang mana $\Delta \tau$ dan $\Delta \sigma n$ masing-masing merupakan perubahan shear stress dan normal stress, $\Delta P$ merupakan perubahan pore-pressure di dalam zona sesar dan $\underline{\mu}$ adalah koefisien friksi. Dalam kondisi undrained, perubahan pore-pressure dapat dihitung dengan:

$$
\Delta P=-B \frac{\Delta \sigma i i}{3}
$$

yang mana $B$ adalah koefisien Skempton dan $\Delta \sigma i i$ adalah tensor stress. Jika $\Delta \sigma n=\frac{\Delta \sigma i i}{3}$ di dalam bidang sesar, maka dapat dihitung perubahan Coulomb stress sebagai berikut:

$$
\Delta C F F=\Delta \tau+\mu^{\prime} \Delta \sigma n
$$

yang mana $\mu^{\prime}$ adalah koefisien friksi efektif dengan $\mu^{\prime}=(1-B) \mu$. Nilai dari koefisien friksi bervariasi dari 0 hingga 0,8 tergantung kondisi pada sesar. Dalam studi ini digunakan nilai koefisien friksi $\mu^{\prime}=0,4$. Pemodelan Coulomb stress dihitung pada sesar utama itu sendiri sebagai sesar penerima (receiver fault) dengan geometri strike $=347^{\circ}$, dip $=70^{\circ}$ dan rake $=210^{\circ}$.

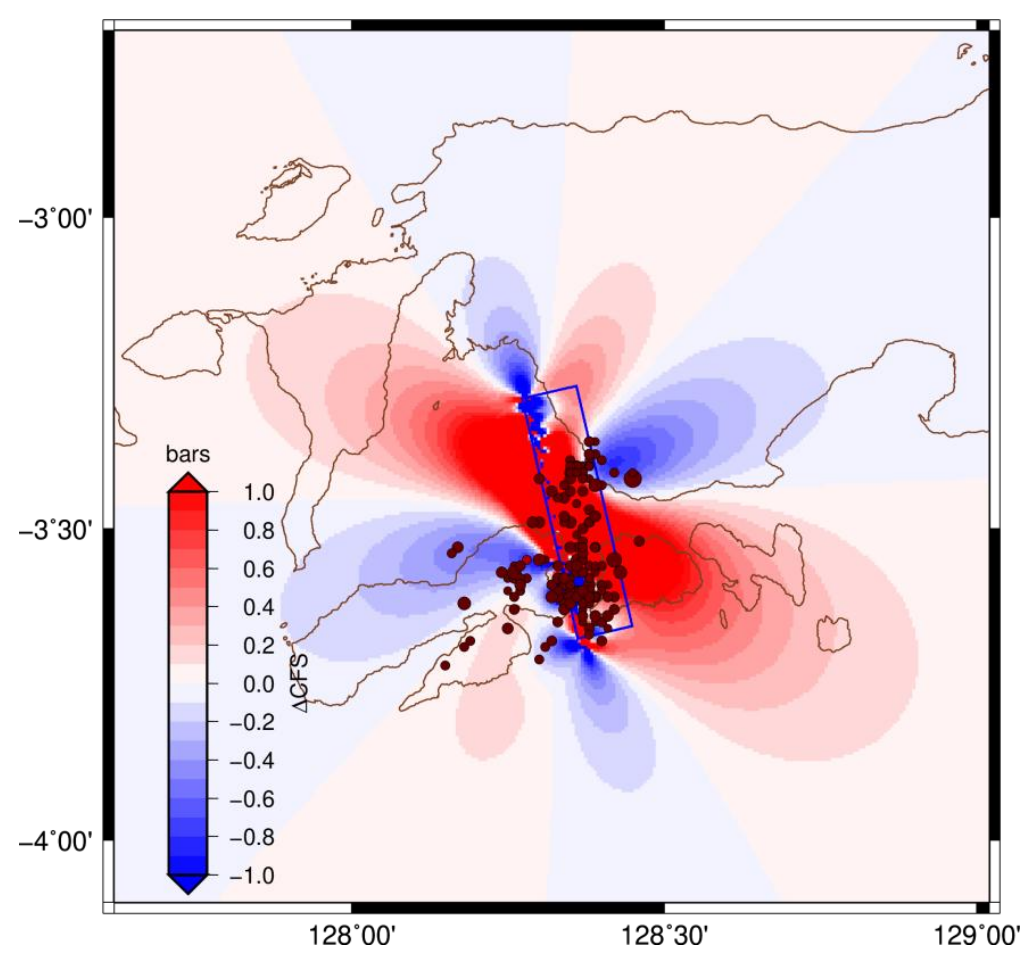

Gambar 3. Perubahan Coulomb stress akibat gempa Ambon 2019 pada kedalaman dangkal 5 $\mathrm{km}$ pada sesar penerima dengan strike $=347^{\circ}$, dip $=70^{\circ}$, dan rake $=210^{\circ}$. Bulat cokelat merupakan episenter gempa susulan $\mathrm{M}>3.0$. 
Pemodelan Coulomb stress menggunakan masukan slip hasil inversi menunjukkan bahwa gempa susulan dipromosikan oleh perubahan Coulomb stress yang positif pada kedalaman yang lebih dangkal $(0-10 \mathrm{~km})$. Secara umum, seperti yang dimodelkan pada Gambar 3, aftershocks berada di zona yang menerima perubahan Coulomb stress positif (warna merah). Dalam peta tersebut ditampilkan distribusi aftershocks $\mathbf{M}>3,0$, yang dianggap memiliki ketidakpastian episenter yang lebih kecil. Gempa susulan ini perlu direlokasi lagi untuk memperbaiki kedalaman hiposenternya. Di sisi lain, aftershocks di bagian barat-daya sesar (di bagian Pulau Ambon) lebih cocok dipromosikan oleh perubahan Coulomb stress positif pada kedalaman yang lebih dalam $(10-30 \mathrm{~km})$ seperti yang ditunjukkan pada Gambar 4.

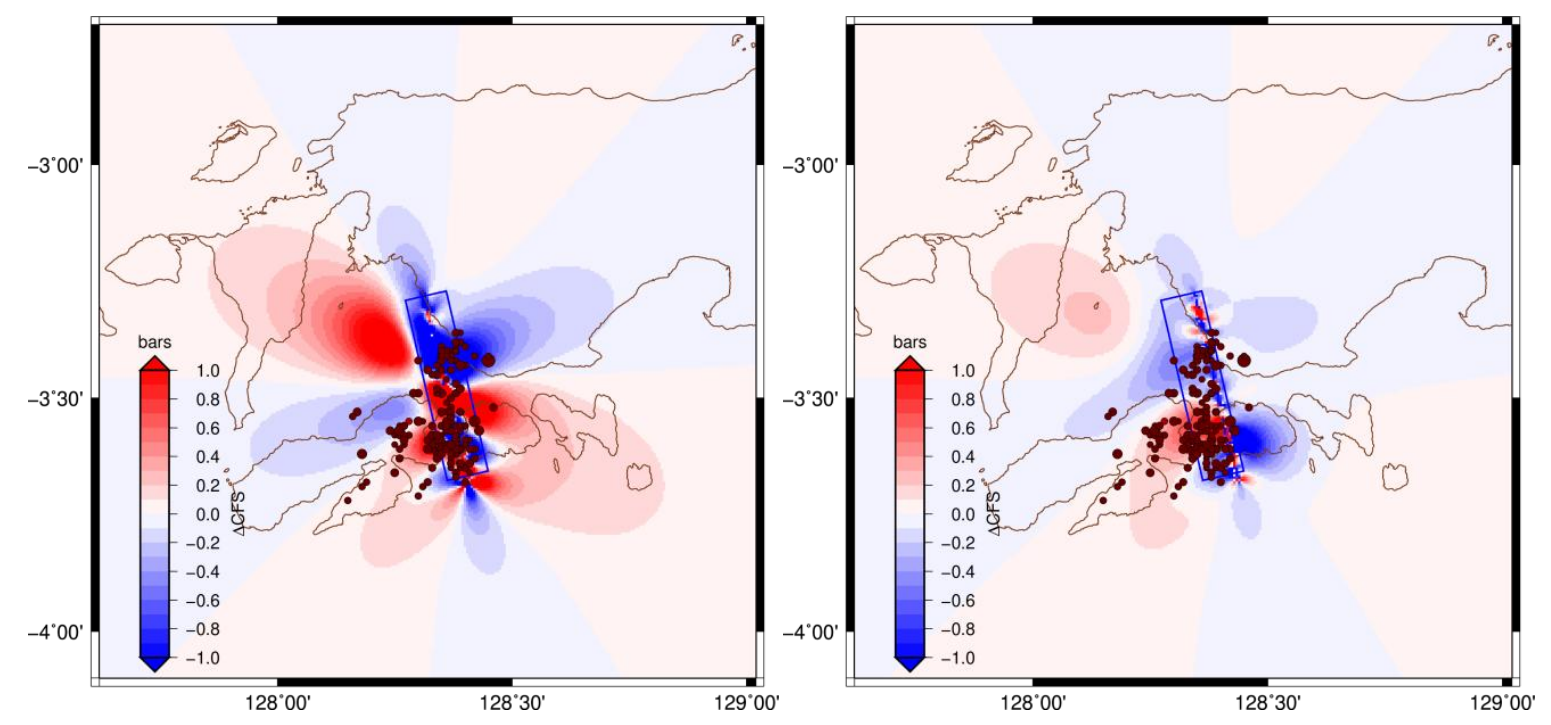

Gambar 4. Perubahan Coulomb stress akibat gempa Ambon 2019 pada kedalaman $15 \mathrm{~km}$ (kiri) dan $25 \mathrm{~km}$ (kanan) pada sesar penerima dengan strike $=347^{\circ}$, dip $=70^{\circ}$, dan rake $=210^{\circ}$.

\section{Diskusi dan Kesimpulan}

\subsection{Limitasi}

Inversi menggunakan data gelombang badan teleseimik saja tidak sensitif terhadap lokasi spasial heterogenitas slip di zona sesar. Biasanya analisis menggunakan gabungan dengan data lokal (near field) penting untuk melihat heterogenitas slip dengan rinci. Tetapi data teleseismik cukup mampu memberikan gambaran besar ukuran dan pergerakan rupture seperti yang ditunjukkan dalam studi ini. Data teleseismik memberikan resolusi temporal yang baik yang membantu dalam menunjukkan evolusi dari rilis momen, seberapa cepat dan seberapa jauh rupture dapat menjalar, dan rilis energi. Di sini juga digunakan gelombang permukaan (surface waves) yang dapat meningkatkan resolusi distribusi slip sepanjang arah down-dip (Hao dkk., 2013). Penggunaan gelombang permukaan frekuensi sangat rendah ini juga dapat meningkatkan resolusi dari total momen seismik yang dihasilkan saat gempa utama (koseismik).

\subsection{Asperity dan Kedalaman seismogenik}

Seperti yang dilihat pada Gambar 2, asperity gempa Ambon berada pada kedalaman yang dangkal yaitu pada kedalaman kurang dari $10 \mathrm{~km}$. Luas asperity pada umumnya sekitar 20\% dari luas rupture (Murotani dkk., 2008), tetapi untuk gempa Ambon 2019, luas asperity sedikit lebih besar yaitu $25 \%$ dari luas rupture. Secara umum, pada model konseptual sesar strike-slip, rupture dapat terjadi pada kedalaman 0 - 15 km (Burgmann, 
2018) atau disebut sebagai zona seismogenik. Zona ini memiliki sifat paling brittle. Gempa Ambon 2019 tampaknya mengikuti pola umum dari tipe sesar strike slip. Pada kedalaman $6 \mathrm{~km}$ di zona seismogenik, biasanya suhu mencapai $180^{\circ} \mathrm{C}$ dan meningkat ke $360^{\circ} \mathrm{C}$ pada kedalaman $12 \mathrm{~km}$. Mekanisme deformasi pada wilayah ini dapat berupa frictional faulting dan juga pressure solution creep. Wilayah pada kedalaman 0-6 km merupakan wilayah yang stabil tetapi rupture dapat menjalar melalui bagian ini seperti pada gempa Ambon 2019. Sementara, kedalaman 6-12 km merupakan kedalaman yang ideal sebagai zona seismogenik untuk proses nukleasi rupture gempa besar. Sementara itu, kedalaman 12-15 km biasanya merupakan zona transisi antara seismik dan aseismik.

Di bagian bawah dari zona seismogenik ini dapat menjadi sumber dari sinyal-sinyal aseismik seperti creeping events, small repeating earthquakes (repeaters) dan tremor tektonik. Hal ini untuk mengakomodasi transisi aseismik dari zona yang sifatnya brittle ke yang lebih ductile. Hal ini didukung dengan observasi gempa pendahuluan (foreshocks) yang terjadi pada gempa Ambon 2019. Gempa pendahuluan seringkali berasosiasi dengan sinyal-sinyal aseismik sebagai manifestasi dari slip yang lambat (slow-slips) pada proses nukleasi sumber gempa utama (Gomberg, 2018, Burgmann, 2018). Pembebanan stress terkonsentrasi pada batas transisi brittle-ductile ini yang sering terobservasi lewat foreshocks. Pembuktian dari dugaan ini perlu dilakukan dengan menganalisis lebih rinci sinyal seismik yang bersumber dari zona ini. Di bagian selatan gempa Ambon 2019 ini, yaitu di bagian antara Pulau Ambon dan Haruku, juga ada kealpaan asperity, yang menunjukkan tanda-tanda bahwa zona ini merupakan bagian yang tidak terkunci (creeping). Gempa-gempa pendahuluan (foreshocks) dalam kasus Ambon 2019 juga terjadi di zona bagian selatan ini (Gambar 1).

\subsection{Stress drop rendah}

Dalam studi ini, didapatkan gempa Ambon 2019 memiliki nilai stress drop yang rendah yaitu 0,2-0,4 MPa. Untuk tipikal gempa tektonik, nilai median stress drop sekitar 3-4 $\mathrm{MPa}$. Gempa-gempa dalam lempeng (intraplate) biasanya memiliki nilai stress drop yang lebih besar dari gempa akibat subduksi (interplate). Gempa strike slip juga seringkali memiliki stress drop yang lebih besar (Allmann dan Shearer, 2009).

Nilai stress drop yang rendah diduga berasal dari sifaf mekanis yang lemah pada lapisan kerak. Lapisan kerak di sekitar wilayah gempa memiliki kekuatan yang lemah. Hal ini merefleksikan lapisan kerak di wilayah gempa tersebut mempunyai sifat yang lebih brittle dan rentan terhadap akumulasi strain yang tinggi karena adanya barrier dan asperity yang mengontrol proses rupture di zona sesar. Nilai stress drop yang rendah juga dapat menunjukkan keterlibatan fluida yang signifikan pada proses rupture. Keterlibatan mekanisme aseismik juga dapat menjadi alasan nilai stress drop yang rendah. Nilai stress drop yang rendah juga diamati pada kejadian gempa swarm dan slow earthquakes.

\subsection{Gempa-gempa pendahuluan}

Penelitian sebelumnya menunjukkan bahwa kasus kemunculan foreshocks lebih jarang terjadi pada gempa intraplate dibandingkan dengan gempa subduksi (interplate) (Bouchon dkk., 2013). Tetapi, gempa Ambon 2019 yang intraplate didahului oleh rangkaian gempa pendahuluan atau foreshocks. Pada Gambar 1, dapat dilihat bahwa gempa pendahuluan muncul di bulan Januari di bagian utara dekat initial break gempa utama, kemudian berhenti di bulan Maret-Mei 2019. Foreshocks kembali muncul di zona bagian utara ini pada bulan Juni-September 2019 dan aktivitasnya semakin meningkat hingga inisiasi gempa utama. Hal ini terlihat jelas di distribusi spasial dan temporal dan jumlah kumulatif gempa yang dipetakan di Gambar 1. Di bulan Agustus 
2019 atau sekitar satu bulan sebelum gempa utama, foreshocks juga muncul di bagian selatan dari zona rupture gempa utama. Kluster foreshocks ada di kedua ujung dari rupture gempa utama dan observasi ini penting untuk studi nukleasi sumber gempa.

Dalam ilmu statistik seismologi, distribusi frekuensi-magnitudo gempa dapat dilihat dari parameter $b$-value yang berasal dari hubungan:

$$
\log N=a-b M
$$

yang mana $N$ adalah jumlah kumulatif dari gempa dengan magnitudo di atas $\mathrm{M}$ (di atas magnitudo kelengkapan $M c$ ), $a$ mendeskripsikan produktivitas, dan $b$ merupakan ratarata distribusi ukuran gempa. Nilai konstanta $b$ (disebut $b$-value) sensitif dan berkebalikan terhadap differential stress batuan. Nilai $b$-value pada umumnya adalah 1,0 untuk gempa-gempa tektonik. Pada banyak kasus, rangkaian foreshocks memiliki nilai $b$ value yang rendah/turun yang artinya zona sesar memiliki differential stress batuan yang tinggi/meningkat (Gulia dan Wiemer, 2019). Pada Gambar 5 disajikan bahwa foreshocks


foreshocks pada gempa Ambon 2019 mungkin berkaitan dengan pembahasan pada subbagian 4.2 dan 4.3 di atas.



Gambar 5. Nilai $b$-value rangkaian foreshocks $(\mathrm{N}=38, M c=2,0)$

\subsection{Gempa-gempa susulan}

Aftershocks gempa Ambon 2019 mempunyai nilai $b$-value 0,93 apabila menggunakan data dengan magnitudo kelengkapan $M c=3,0$ (Gambar 6). Menggunakan nilai $M c$ yang lebih tinggi yaitu 4,0 didapatkan nilai b-value aftershocks sebesar 1,04. Hal ini artinya gempa susulan sudah merefleksikan nilai normal $b$-value gempa tektonik yaitu mendekati 1,0. Apabila mempertimbangkan nilai $M c$ yang lebih kecil $(M c=2,0)$, didapatkan nilai $b$-value yang bertahan di level yang rendah $(b=0,55 \pm 0,05)$. Hal ini perlu dianalisis apakah ini berkaitan dengan ketidaklengkapan katalog atau berhubungan dengan mekanisme fisis yang berlangsung setelah gempa utama yang mungkin berkaitan dengan pembahasan pada sub-bagian 4.2 dan 4.3.

Produktivitas gempa-gempa susulan dalam kasus gempa Ambon 2019 ini tergolong cukup tinggi (Gambar 7). Hal ini mungkin disebabkan oleh gempa utama yang memiliki nilai stress drop yang rendah. Gempa dengan stress drop yang rendah cenderung memproduksi aftershocks yang lebih banyak (Wetzler dkk., 2016). 


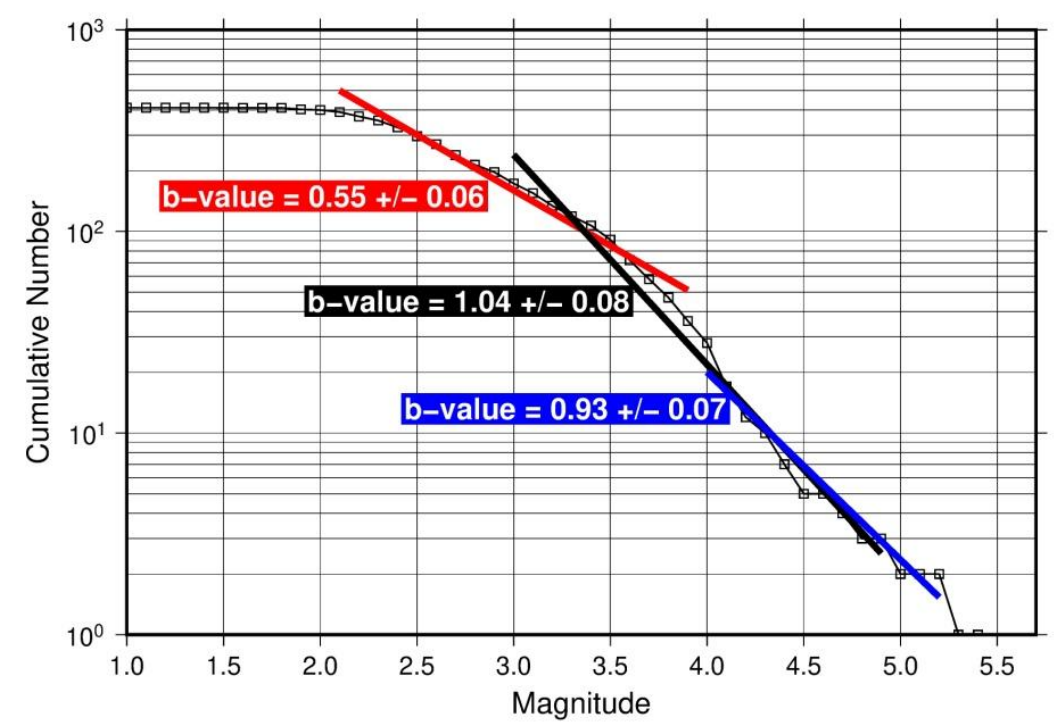

Gambar 6. Nilai $b$-value rangkaian aftershocks $(\mathrm{N}=411, M c=2,0$ :merah, 3,0:hitam dan 4,0:biru)

Aftershocks dapat dianalisis dengan laju peluruhan aftershocks $R(t)$ dengan rumus:

$$
R(t)=\frac{K}{(t+c)^{p}}
$$

yang mana $t$ adalah waktu sejak mainshock; $K$ mendeskripsikan produktivitas aftershocks yang tergantung pada magnitudo gempa utama; $c$ dan $p$ adalah konstanta empiris. Rumus ini dikenal sebagai modified Omori's law. Nilai $p$-value secara global adalah 1,0 tetapi fluktuasinya bervariasi antara tiap mainshock. Nilai p-value yang rendah menunjukkan peluruhan yang lambat (slow decay) dari aktivitas gempa susulan. Pada Gambar S6 dan S7 disajikan hasil fitting peluruhan aftershocks yang menunjukkan gempa Ambon 2019 mempunyai nilai p-value 0,60 (untuk aftershocks di atas $M c=2,5$ ) dan 0,76 untuk aftershocks di atas $M c=3,0$ ). Hal ini menunjukkan bahwa gempa Ambon 2019 mempunyai laju peluruhan aftershocks yang lambat (Gambar 7 dan S8).

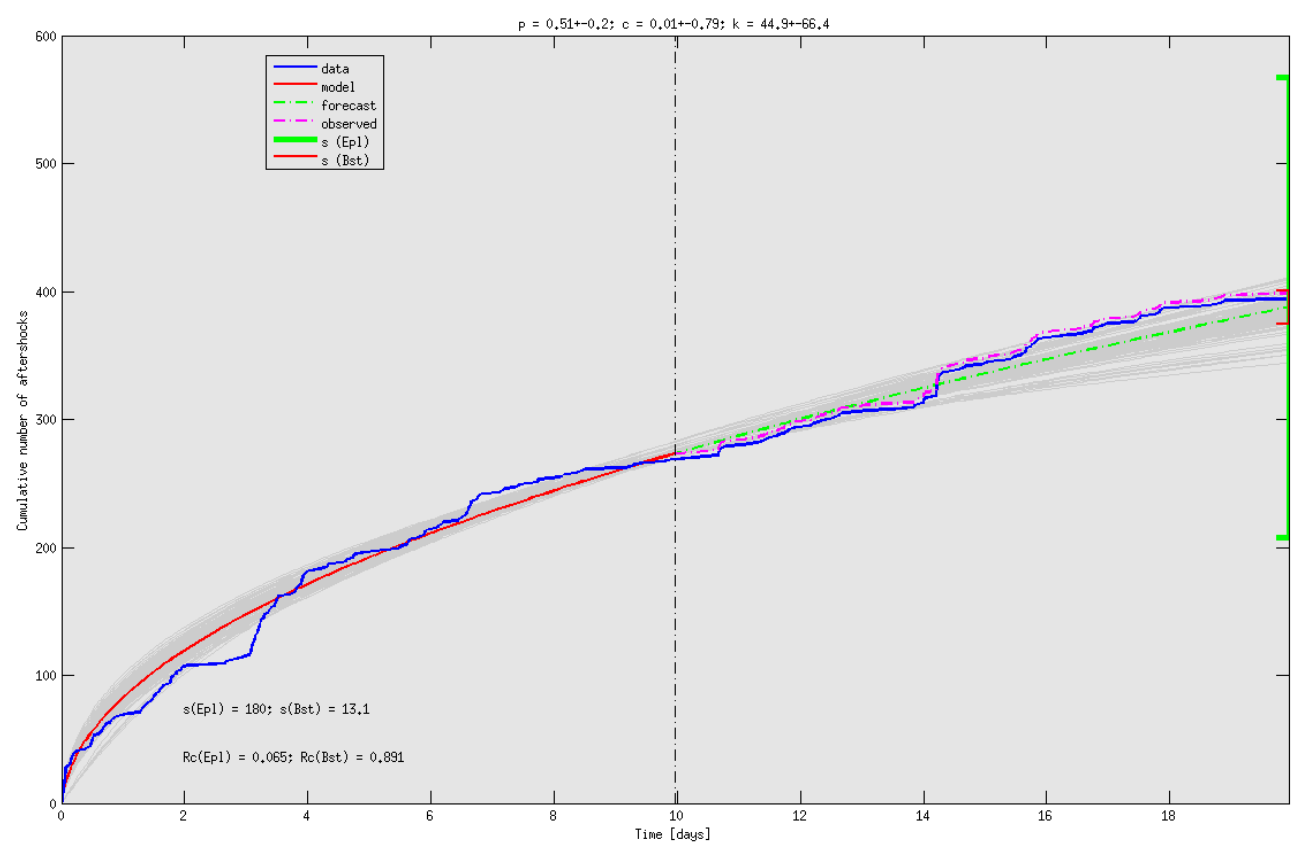

Gambar 7. Prakiraan aftershocks dalam 10-20 hari sejak gempa utama menggunakan data 0 - 10 hari setelah mainshock. 


\subsection{Implikasi tektonik}

Gempa dengan magnitudo 6,5 dapat terjadi dengan rupture yang kompleks yang melibatkan beberapa segmen, tetapi dalam pemodelan di studi ini, gempa diasumsikan terjadi pada segmen tunggal. Seperti yang disebutkan di atas bahwa keberadaan struktur strike slip dan thrust adalah hal yang wajar di sekitar Pulau Seram sebagai bentuk akomodasi atas deformasi yang kompleks (Watkinson dan Hall, 2017). Model menunjukkan bahwa gempa Ambon 2019 terjadi pada sesar dengan tipe right lateral strike slip berarah selatan-utara. Sesar ini diperkirakan berada di antara pulau Ambon dan Haruku memanjang ke utara di sekitar barat daya Kairatu, Pulau Seram. Pada Gambar 8 ditunjukkan posisi relatif dugaan sesar ini pada tatanan tektonik di sekitar Seram. Terlihat bahwa sesar ini paralel dengan sesar strike slip Buru. Perlu penelitian lebih lanjut untuk membuktikan dugaan sesar yang disampaikan dalam studi ini.



Gambar 8. Posisi sesar penyebab gempa Ambon 2019 relatif terhadap tatanan tektonik di sekitar Pulau Seram. Juga dipetakan episenter gempa yang terjadi selama 1 Januari - 18 Oktober 2019. Garis biru merupakan struktur sesar aktif yang ada pada Peta Sumber dan Bahaya Gempa Indonesia 2017.

\subsection{Kesimpulan}

a. Gempa Ambon 2019 bersumber dari penyesaran mendatar dekstral dan bilateral dengan orientasi selatan-utara. Ukuran rupture sekitar $34 \times 17 \mathrm{~km}^{2}$, rata-rata slip 29,4 $\mathrm{cm}$ dan slip maksimum 90,1 cm. Ukuran asperity sekitar $25 \%$ dari ukuran rupture dan berada di kedalaman dangkal kurang dari $10 \mathrm{~km}$. Total momen seismik gempa ini setara dengan magnitudo momen 6,47.

b. Gempa ini memiliki stress drop yang tergolong rendah.

c. Sebaran aftershocks dapat dijelaskan dengan perubahan Coulomb stress statik positif pada kedalaman dangkal $(0-10 \mathrm{~km})$.

d. Aftershocks memiliki laju peluruhan yang lambat (slow decay rate). 


\section{Ucapan Terima kasih}

Data gempabumi bersumber dari katalog Pusat Gempabumi dan Tsunami Badan Meteorologi, Klimatologi dan Geofisika (BMKG). Data teleseismik diunduh dari The Global Seismographic Network (GSN) Incorporated Research Institutions for Seismology (IRIS) (http://ds.iris.edu/wilber3/find_event). Kami mengucapkan terima kasih kepada petugas Pusat Gempabumi dan Tsunami BMKG dan Stasiun Geofisika Karang Panjang Ambon atas diskusi tentang gempa Ambon 2019.

\section{Referensi}

Allmann, B.P. dan Shearer, P.M., 2009. Global variations of stress drop for moderate to large earthquakes. Journal of Geophysical Research: Solid Earth, 114(B1).

Bouchon, M., Durand, V., Marsan, D., Karabulut, H. dan Schmittbuhl, J., 2013. The long precursory phase of most large interplate earthquakes. Nature Geoscience, 6(4), p.299.

Bürgmann, R., 2018. The geophysics, geology and mechanics of slow fault slip. Earth and Planetary Science Letters, 495, pp.112-134.

Gomberg, J., 2018. Unsettled earthquake nucleation. Nature Geoscience, 11(7), p.463.

Gulia, L. dan Wiemer, S., 2019. Real-time discrimination of earthquake foreshocks and aftershocks. Nature, 574(7777), pp.193-199.

Hao, J., Ji, C., Wang, W. dan Yao, Z., 2013. Rupture history of the 2013 Mw 6.6 Lushan earthquake constrained with local strong motion and teleseismic body and surface waves. Geophysical Research Letters, 40(20), pp.5371-5376.

Ji, C., Wald, D.J. dan Helmberger, D.V., 2002. Source description of the 1999 Hector Mine, California, earthquake, part I: Wavelet domain inversion theory and resolution analysis. Bulletin of the Seismological Society of America, 92(4), pp.1192-1207.

Kanamori, H. dan Anderson, D.L., 1975. Theoretical basis of some empirical relations in seismology. Bulletin of the seismological society of America, 65(5), pp.1073-1095.

Lin, X., Chu, R. dan Zeng, X., 2019. Rupture processes and Coulomb stress changes of the 2017 Mw 6.5 Jiuzhaigou and 2013 Mw 6.6 Lushan earthquakes. Earth, Planets and Space, 71(1), p.81.

Mai, P.M. dan Beroza, G.C., 2000. Source scaling properties from finite-fault-rupture models. Bulletin of the Seismological Society of America, 90(3), pp.604-615.

Murotani, S., Miyake, H. dan Koketsu, K., 2008. Scaling of characterized slip models for plate-boundary earthquakes. Earth, planets and space, 60(9), pp.987-991.

Shao, G., Li, X., Ji, C. dan Maeda, T., 2011. Focal mechanism and slip history of the $2011 \mathrm{M}$ w 9.1 off the Pacific coast of Tohoku Earthquake, constrained with teleseismic body and surface waves. Earth, planets and space, 63(7), p.9. 
Watkinson, I.M. dan Hall, R., 2017. Fault systems of the eastern Indonesian triple junction: evaluation of Quaternary activity and implications for seismic hazards. Geological Society, London, Special Publications, 441(1), pp.71-120.

Wells, D.L. dan Coppersmith, K.J., 1994. New empirical relationships among magnitude, rupture length, rupture width, rupture area, and surface displacement. Bulletin of the seismological Society of America, 84(4), pp.974-1002.

Wetzler, N., Brodsky, E.E. dan Lay, T., 2016. Regional and stress drop effects on aftershock productivity of large megathrust earthquakes. Geophysical Research Letters, 43(23), pp.12-012.

\section{Lampiran Gambar}



Gambar S1. Model slip untuk bidang nodal kedua $\left(\right.$ strike $=253^{\circ}$, dip $=84^{\circ}$ ) 


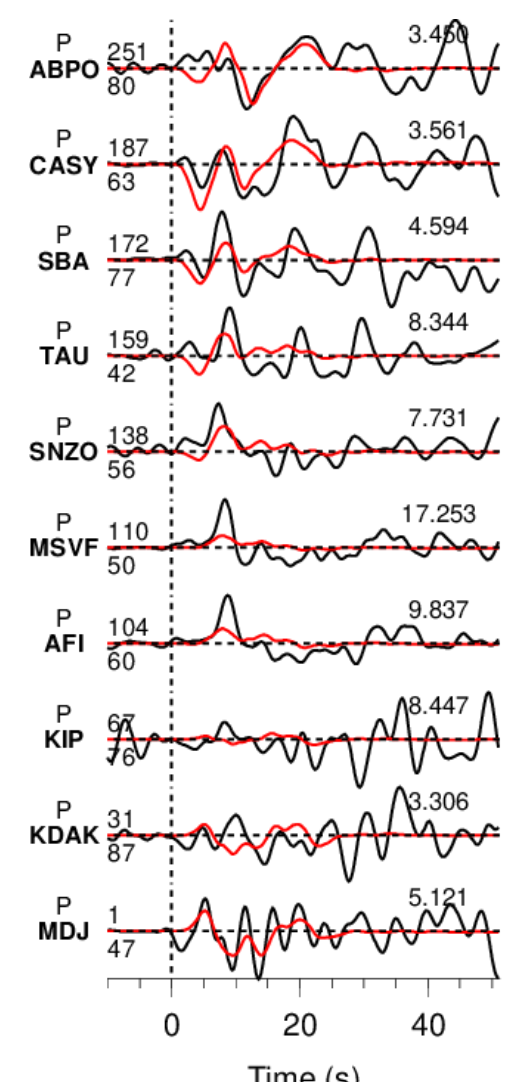

Time (s)

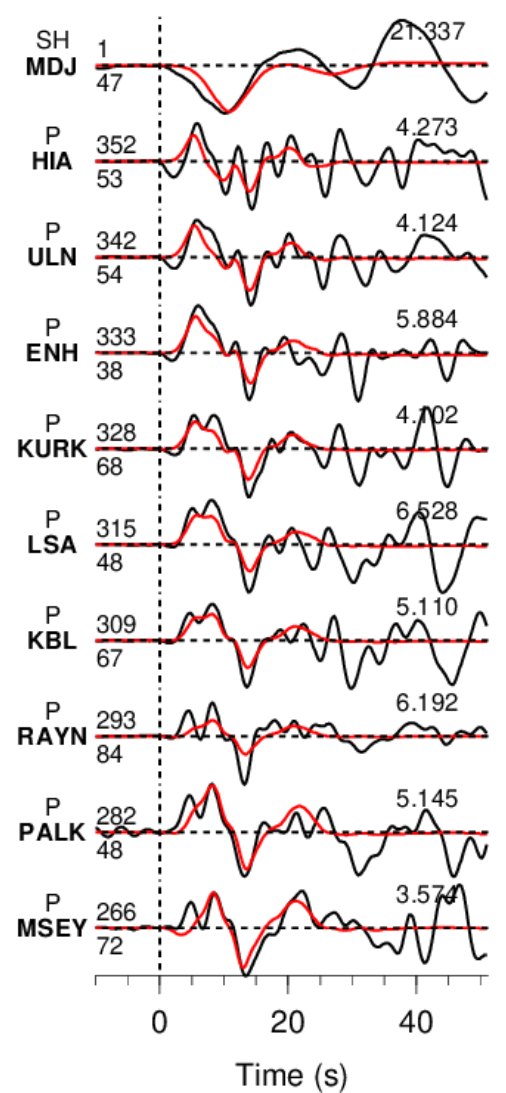

Time (s)
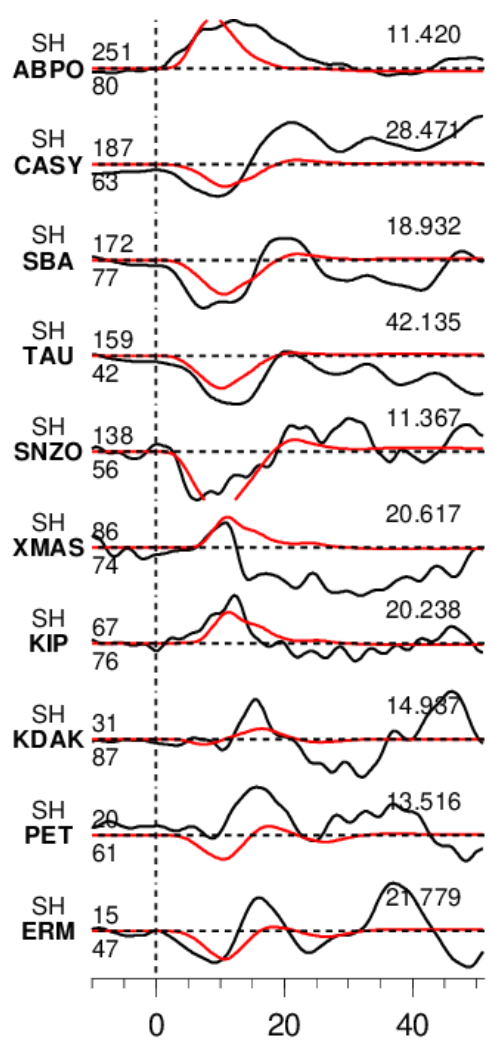

Time (s)



Gambar S2. Waveform fitting untuk model bidang nodal 1. Garis hitam adalah sinyal observasi dan garis merah adalah sinyal sintetik. Label pada awal tiap sinyal menunjukkan komponen dan nama stasiun. Angka pada akhir tiap sinyal menunjukkan amplitudo maksimum sinyal observasi dalam mikrometer. Angka di atas dan bawah dari awal tiap sinyal menunjukkan azimuth stasiun dan jarak stasiun dari pusat gempa (dalam derajat). 



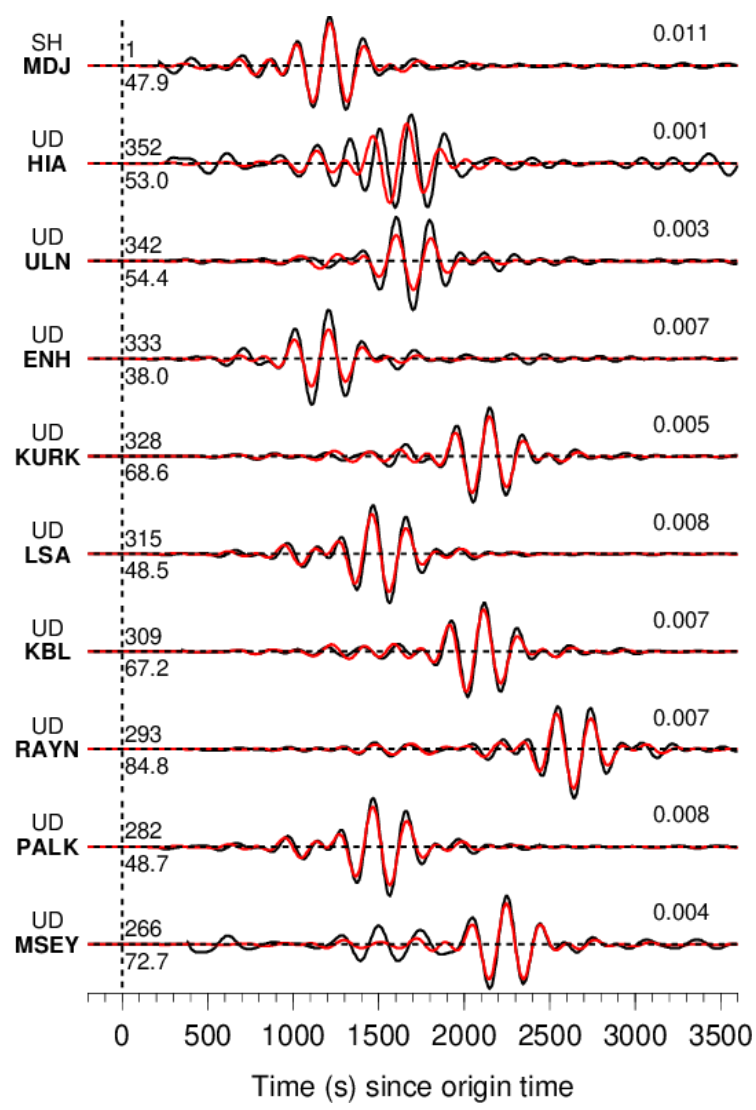

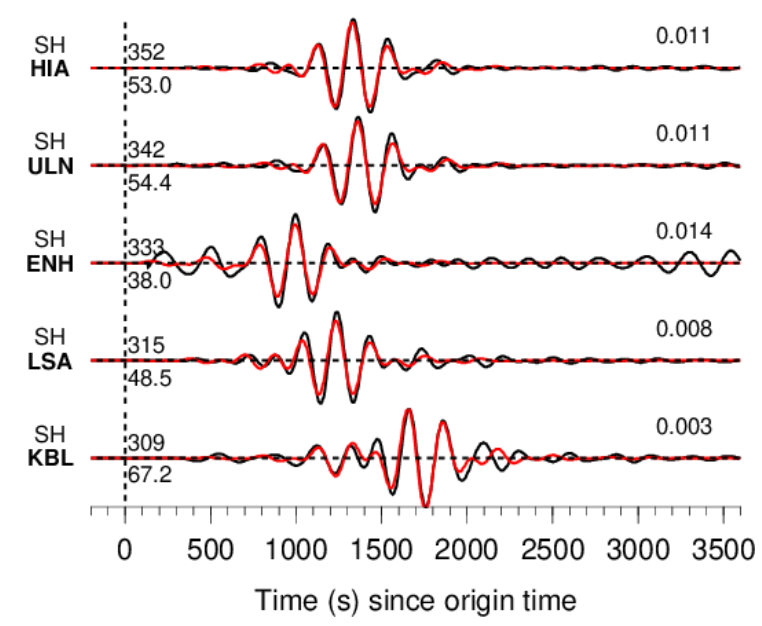

Gambar S3. Sama dengan Gambar S2 tetapi untuk surface wave bidang nodal 1. 

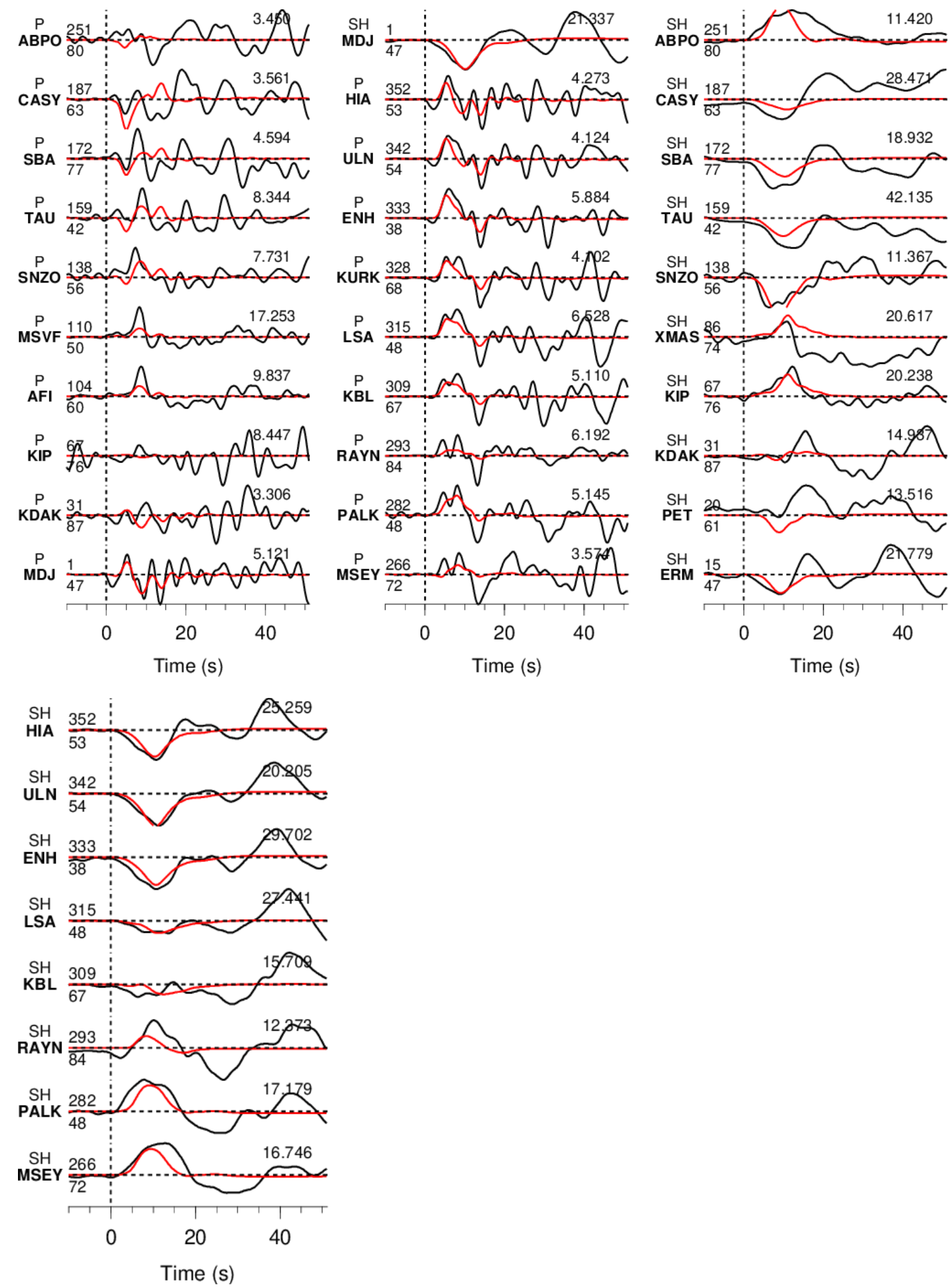

Gambar S4. Sama dengan Gambar S2 tetapi untuk body-wave bidang nodal 2. 

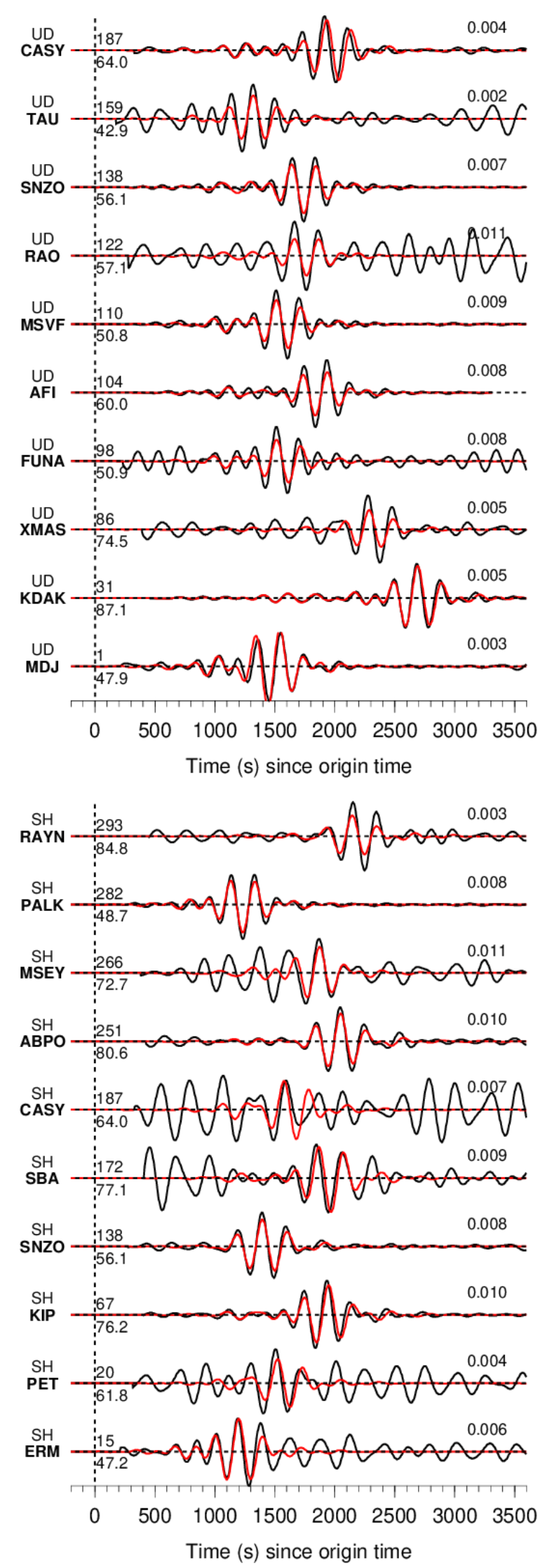

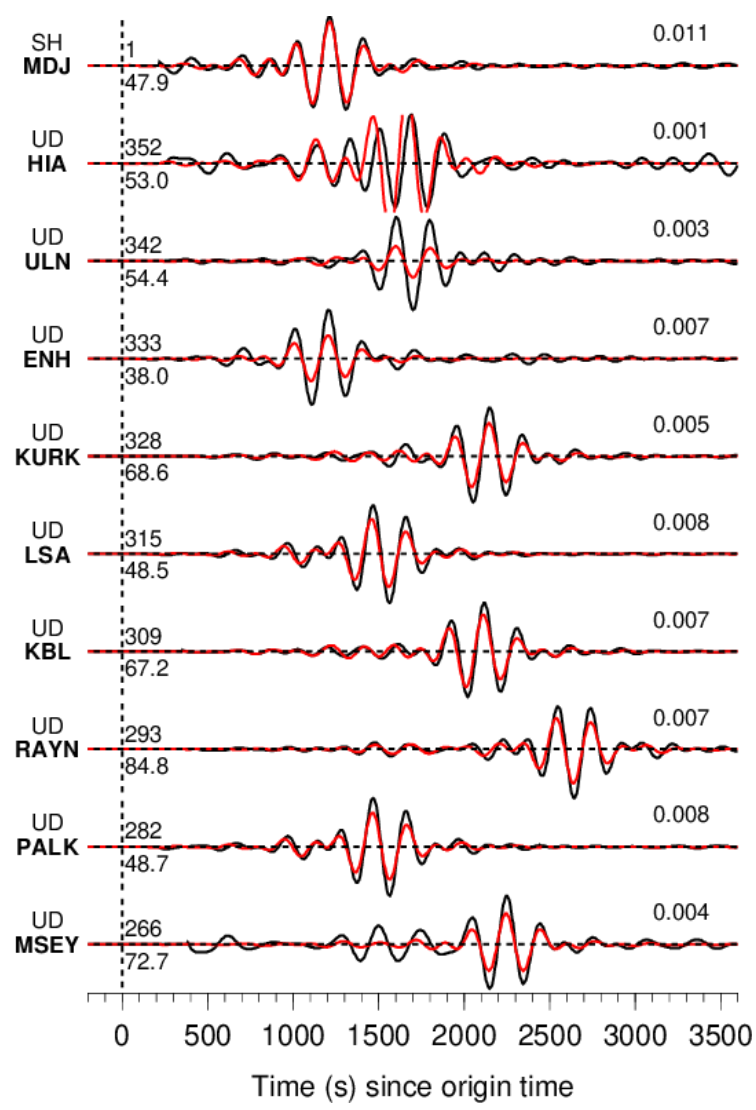

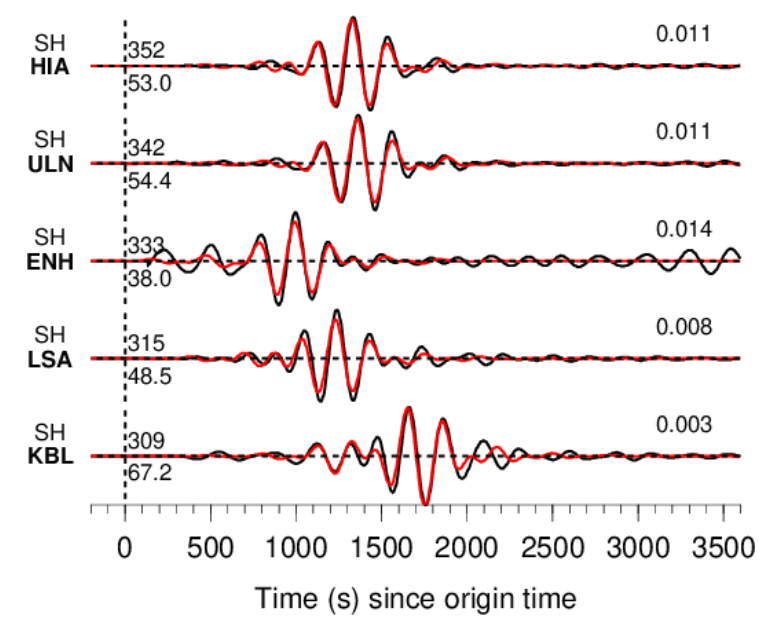

Gambar S5. Sama dengan Gambar S2 tetapi untuk surface-wave bidang nodal 2. 


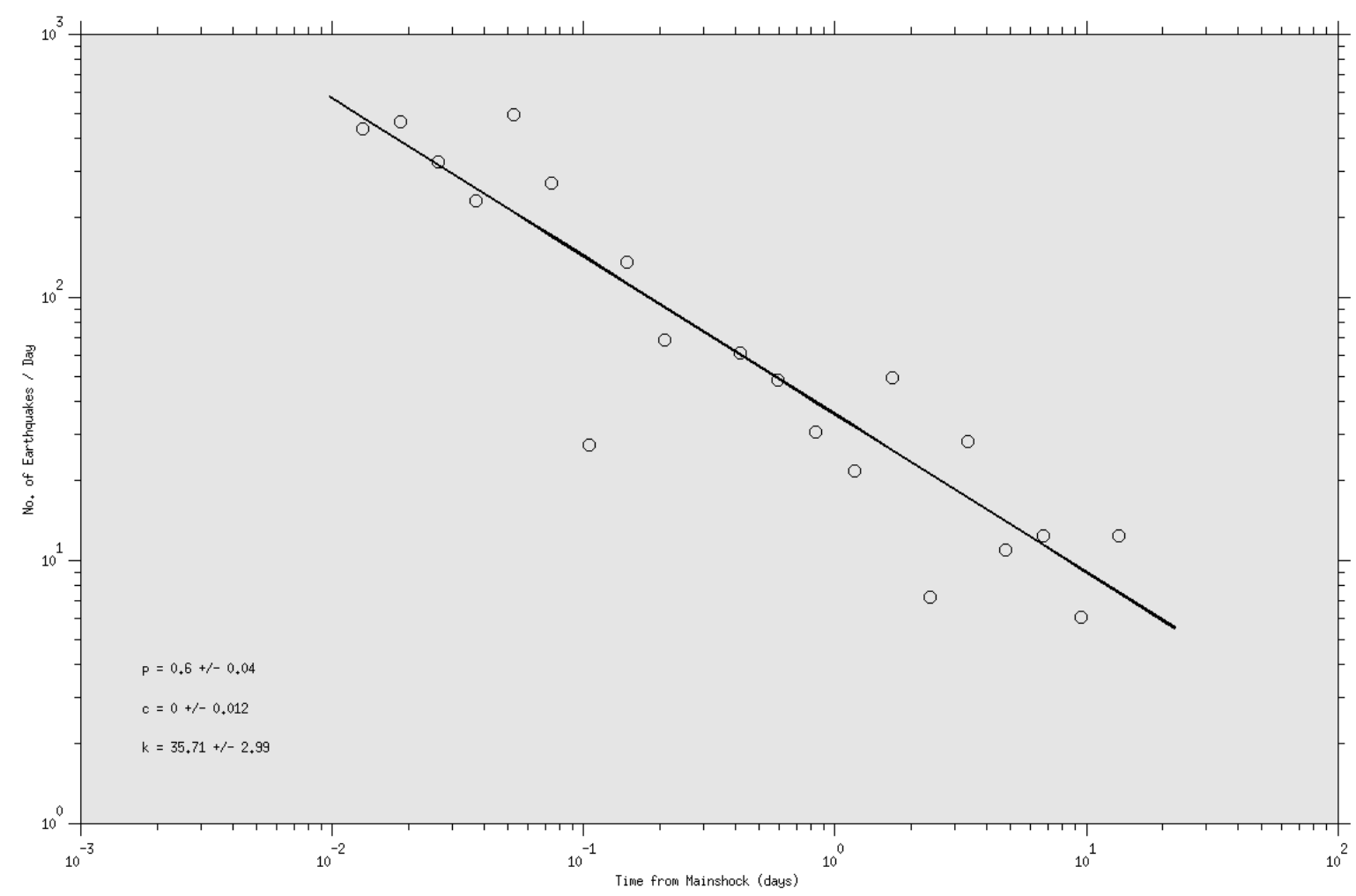

Gambar S6. Fitting untuk peluruhan aftershocks menurut Omori's law dengan Mc=2,5

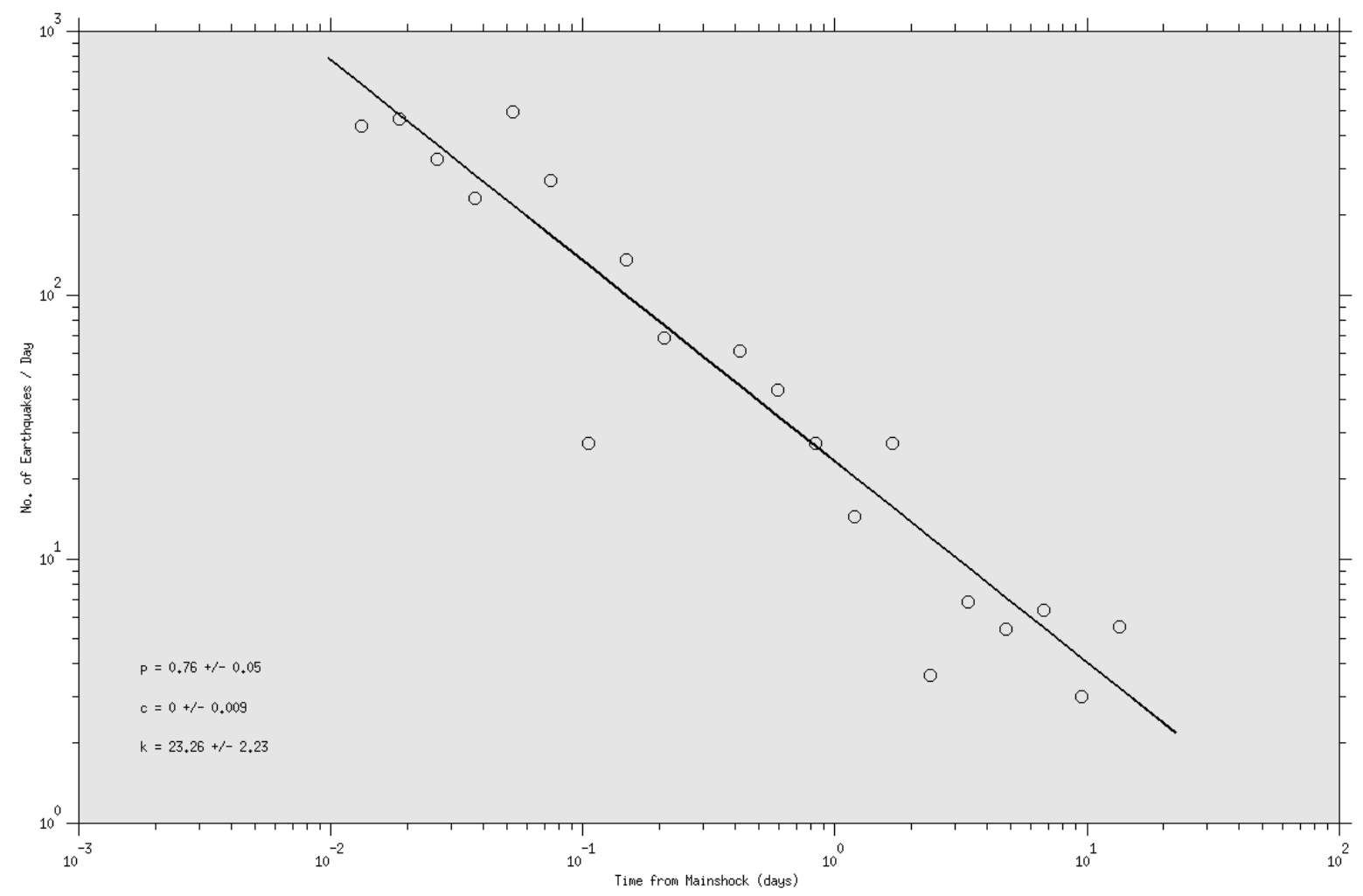

Gambar S7. Fitting untuk peluruhan aftershocks menurut Omori's law dengan Mc=3,0 


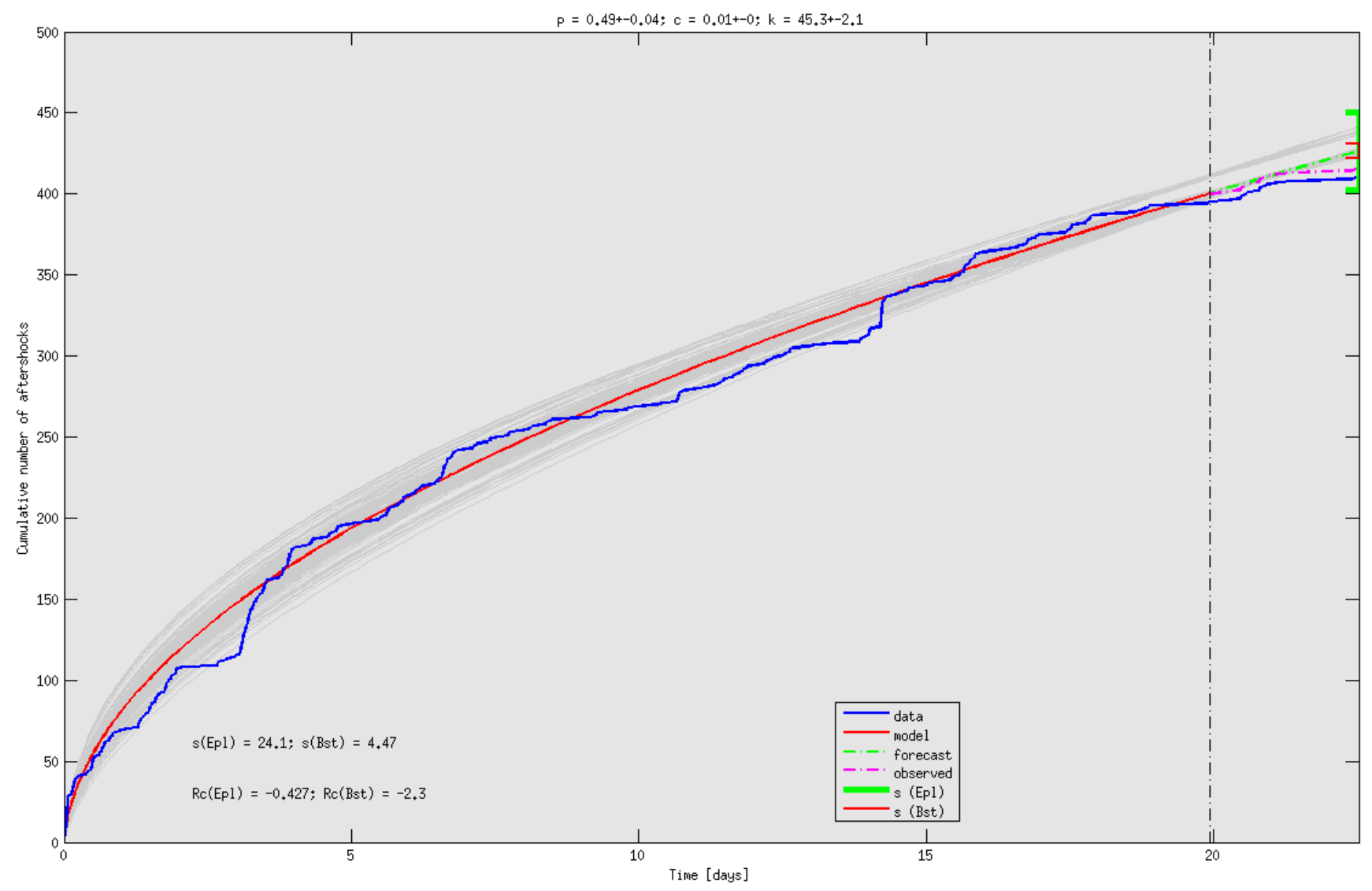

Gambar S8. Forecast aftershocks setelah 20 hari sejak gempa utama menggunakan data 020 hari setelah mainshock. 